NBER WORKING PAPER SERIES

\title{
NONPROFIT BUSINESS ACTIVITY \\ AND THE UNRELATED BUSINESS \\ INCOME TAX
}

James R. Hines, Jr.

Working Paper 6820

http://www.nber.org/papers/w6820

\section{NATIONAL BUREAU OF ECONOMIC RESEARCH \\ 1050 Massachusetts Avenue \\ Cambridge, MA 02138 \\ December 1998}

I thank Jeffrey Brown and Austin Nichols for excellent research assistance, James Poterba and Richard Sansing for helpful comments on an earlier draft, and the NBER for financial support. The views expressed here are those of the author and do not reflect those of the National Bureau of Economic Research.

(C) 1998 by James R. Hines, Jr. All rights reserved. Short sections of text, not to exceed two paragraphs, may be quoted without explicit permission provided that full credit, including $\mathbb{C}$ notice, is given to the source. 
Nonprofit Business Activity and the

Unrelated Business Income Tax

James R. Hines, Jr.

NBER Working Paper No. 6820

December 1998

JEL No. H25, L31

\section{ABSTRACT}

American nonprofit organizations are generally exempt from federal income tax, with the exception that profits earned from activities that are "unrelated" to exempt purposes are subject to the Unrelated Business Income Tax (UBIT). The UBIT is intended to prevent "unfair" competition between tax-exempt nonprofits and taxable for-profit firms, and also to prevent erosion of the federal tax base through tax-motivated transactions between taxable and tax-exempt entities. The evidence indicates that American nonprofit organizations engage in very little unrelated business activity, paying aggregate UBIT of less than $\$ 200$ million annually. Large nonprofit organizations, and those with pressing financial needs due to high program-related expenses and low receipts of contributions and government grants, are the most likely to have unrelated business income. The same organizational characteristics are not associated with earning income from inventory sales that are "related" to exempt purposes. This evidence suggests that nonprofits incur important organizational costs in undertaking unrelated business activity, since unrelated business income is concentrated among organizations facing the strongest financial pressures. This, in turn, carries implications for the efficiency of the UBIT as a source of tax revenue and for the need to tax the business income of nonprofit organizations in order to prevent "unfair" competition.

James R. Hines Jr.

University of Michigan Business School

701 Tappan Street

Ann Arbor, MI 48109-1234

and NBER

jrhines@umich.edu 


\section{Introduction}

Charitable nonprofit organizations in the United States that are eligible for tax exemptions under Internal Revenue Code section 501(c)(3) include religious, educational, charitable, scientific, and literary organizations. These charitable nonprofits spent $\$ 548$ billion on their activities in 1994 (the most recent year for which comprehensive data are available), which represents roughly eight percent of Gross Domestic Product. This is a sizable figure, particularly so since it omits most religious organizations (which do not report their finances to the government), and since spending includes only the compensated portion of nonprofit labor, much of which is provided to nonprofits at zero or below-market wages.

Nonprofit organizations commonly express concern over the difficulties they confront in financing their many activities. Funding for charitable nonprofit organizations comes largely from program service revenues, which generated $\$ 422$ billion in 1994 , or $72 \%$ of their total receipts of $\$ 587$ billion. Other sources of funds include contributions ( $\$ 58$ billion), government grants ( $\$ 52$ billion), and various types of income from investments. ${ }^{1}$

Nonprofit organizations are generally exempt from federal and state income taxes, which distinguishes them from most other private entities - such as corporations, which are currently subject to a federal income tax of $35 \%$. The tax exemption for nonprofits has several important aspects. One is that income earned by nonprofits is largely exempt from tax. A second is that individuals and corporations making qualifying donations to 501(c)(3) organizations are entitled to claim tax deductions for their contributions.

Nonprofit organizations in the United States are not eligible for blanket tax exemptions; 
instead, organizations must apply for and receive tax-exempt status from the U.S. government, and tax exemptions, if granted, are limited. American laws constrain the operating activities and financial behavior of organizations that wish to retain tax exempt status, and impose taxes on certain activities of nonprofit organizations that are otherwise tax-exempt. This paper evaluates one such tax: the Unrelated Business Income Tax (UBIT).

The United States introduced in 1950 a new tax on the "unrelated business income" of certain nonprofit organizations. Congress enacted the UBIT out of concern over the possibility of "unfair competition" between taxable business entities and nonprofit organizations engaging in the same, or similar, activities. The UBIT has been controversial since its enactment, coming under fire from some critics who claim that it imposes unnecessary burdens on nonprofit organizations and others who argue that its scope is insufficiently broad. The purpose of this paper is to review some of the issues raised by the UBIT and to evaluate its impact on charitable nonprofit organizations in the United States.

Certain aspects of the UBIT are clear from the outset. The UBIT raises very little direct revenue for the federal government, the most recent available annual figure (for 1994) being \$195 million. The primary function of the UBIT is to discourage (though not eliminate) unrelated business activity on the part of charitable nonprofits. In doing so, the UBIT reduces the likelihood that nonprofit organizations will compete with taxpaying firms in similar lines of business. The UBIT thereby also maintains that portion of the corporate tax base that would otherwise become the province of tax-exempt entities. Some organizations with opportunities to earn unrelated business income that would be subject to the UBIT opt instead to seek alternative methods of financing their activities, and, in some cases, to scale back their programmatic

\footnotetext{
${ }^{1}$ Hilgert (1998) reports aggregate financial information for 501(c)(3) organizations in 1994.
} 
expenditures.

The empirical work in this paper analyzes the characteristics of organizations with and without unrelated business income in order to identify characteristics of nonprofit organizations that are correlated with unrelated business activity. The results suggest that large organizations are the most likely to have unrelated business income, and that, controlling for asset size, unrelated business activity is concentrated among organizations with high program-related expenses and those receiving few contributions and government grants. This pattern suggests that unrelated business activity is undertaken largely by organizations with both business opportunities and pressing financial needs. Put differently, American nonprofit organizations appear to prefer not to undertake unrelated business activity unless driven to do so by financial necessity.

The difficulty with such an interpretation of the evidence is that the correlations evident in the data need not be causal. An organization with the ability to generate unrelated business income may, all other things equal, be less inclined than other organizations to seek outside funding in the form of contributions or government grants, and may be more willing than others to spend money on active programs. Furthermore, unrelated business activity may discourage private contributors and government granting agencies from providing funds. Since fundraising, programmatic spending, and other operational aspects of nonprofit organizations represent endogenous choices, the direction of causality is not entirely clear.

In order to address the issue of causality, the empirical work in the paper compares organizational characteristics associated with earning unrelated business income with those characteristics associated with earning profits from sales of inventory items. The patterns differ greatly: while large organizations are the most likely to generate both types of revenue, 
organizations receiving higher levels of contributions and government grants, and organizations with lower levels of programmatic spending, are considerably more likely to generate income from sales of inventory items. It appears that it is not commercialism per se that exhibits a positive correlation with program spending and a negative correlation with the receipt of contributions and grants - but a particular form of commercialism that is unrelated to exempt purposes. Such a pattern is consistent with a general reluctance on the part of nonprofit organizations to engage in unrelated business activities.

This evidence implies that fear of "unfair" competition in the marketplace from nonprofit organizations, even in the absence of the UBIT, is generally misplaced. Of course, with so many available definitions of "fairness," this issue is difficult entirely to resolve. Analysis of their incentives indicates that nonprofits organizations have no reason to operate unrelated businesses used for investment purposes any differently than would taxable for-profit competitors in the same lines of business. The tax exemption augments a nonprofit's available resources for business investment; but so, too, do earnings in the other business lines of a large (for-profit) conglomerate, yet the "fairness" issue is seldom raised in the second case. And the evidence suggests that nonprofit organizations are generally less eager than their for-profit counterparts to undertake business ventures unrelated to their charitable purposes, typically doing so only when pushed by financial necessity.

From a tax policy standpoint, it has been noted that the UBIT removes the tax incentive nonprofit organizations would otherwise have to own and operate corporate entities instead of merely owning their shares. In the absence of a UBIT, the corporate tax can be avoided by undertaking business activity entirely within a nonprofit organization. The UBIT introduces at 
least as many distortions as it removes, however, since nonprofit organizations do not pay taxes on most of their capital income. Introduction of the UBIT widens the tax wedge between earning capital income in the form of interest and earning income from unrelated business activities. In addition, the UBIT is the source of extensive compliance and enforcement difficulties that stem from the vagueness of operational distinctions between business income that is "related" and "unrelated" to charitable purposes, and from the difficulty of allocating joint costs between charitable and business operations.

Section two reviews the tax treatment of income earned by nonprofit organizations. Section three evaluates the incentives created by the UBIT and their implications for the efficiency of resource allocation. Section four considers aggregate patterns of unrelated business activity by nonprofit organizations. Section five analyzes the commercial behavior of individual nonprofit organizations, devoting special attention to the differing characteristics of organizations with unrelated business income and those with income from selling inventory items that are related to their charitable purposes. Section six is the conclusion.

\section{The (Limited) Tax Exemption for Nonprofit Organizations}

Organizations dedicated to various objectives deemed by Congress to be sufficiently worthy are granted exemptions from federal and state income taxes. There are two important aspects of this exemption: the first is that organizations must receive their exemptions from the U.S. Treasury; for this they must apply, and many applications are denied. The second is that the 
exemption is partial: not all activities of nonprofit organizations are exempt from federal income tax. Once a 501(c)(3) organization has a tax exemption, qualifying contributions are deductible against the taxable incomes of contributors, so tax exemptions are valuable quite beyond the ability they confer to avoid tax on business income.

The U.S. corporate income tax was introduced in 1913, at which time nonprofit organizations were granted exemptions from the tax. ${ }^{2}$ In the late 1940s, public outcry over various business acquisitions by some highly visible nonprofit organizations motivated Congress to reevaluate the tax exemption for nonprofits. In 1950, Congress introduced the Unrelated Business Income Tax (UBIT), to which nonprofit organizations are subject. The UBIT is very similar in structure and rate to the corporate income tax, with the difference that it applies only to certain sources of income.

The UBIT is a tax on income earned in a manner that is "unrelated" to a nonprofit organization's charitable purpose. Thus, art museums are not required to pay UBIT on profits earned from sales of art reproductions in museum shops. But art museums are required to pay UBIT on profits earned from sales in their shops of "unrelated" items, such as magazines or pain relievers. Ticket sales for its college football games are not taxable to a university, but income generated by renting its sports facility to a professional team is subject to the UBIT. Advertising revenue is generally taxable under the UBIT. Most types of capital income are explicitly exempted from the UBIT, so that, for example, educational institutions are not subject to UBIT on interest, dividends, and capital gains earned by their endowment funds. An important exception is that debt-financed investments are subject to the UBIT.

\footnotetext{
${ }^{2}$ See Bittker and Rahdert (1976) for a survey of the history of the exemption of nonprofit organizations from federal income taxation. Simon (1987) reviews the taxation of nonprofit
} 
The fact that a nonprofit organization uses the income that it earns to further its exempt purpose does not imply that any income-earning activities are therefore "related" to the purpose and consequently exempt from the UBIT. Income is subject to the UBIT based on the way in which it is earned, not the way in which it is used. The UBIT provisions are intended to prevent "unfair" competition between nonprofit organizations and taxable competitors and to protect the integrity of the tax base from erosion due to tax-motivated transactions between taxed and untaxed entities. There are, however, many practical difficulties that arise in distinguishing "related" from "unrelated" income, ${ }^{3}$ as well as in identifying debt-financed investments that are designed to exploit a nonprofit organization's tax-exempt status for investment purposes. The government can remove the tax-exempt status of organizations earning excessive unrelated business income, and this possibility, together with various differences between the UBIT and the regular corporate tax, has motivated some nonprofits to locate income-generating activities in wholly-owned taxable subsidiaries that are subject to corporate taxation.

\section{Efficiency Consequences of the UBIT}

The UBIT applies to a subset of the commercial activities of nonprofit organizations. The controversy over this tax focuses on two issues. The first concerns whether, in the absence of the UBIT, tax-exempt nonprofit organizations would have "unfair" commercial advantages over forprofit, taxpaying, firms engaged in the same or similar lines of business. The second is whether

organizations more generally.

${ }^{3}$ See, for example, U.S. General Accounting Office (1987, pp. 24-25), describing the difficulties facing the IRS in determining the "relatedness" of various income-producing activities and costs appropriately deducted against "unrelated" business income. 
the UBIT in its current form improves the efficiency of resource allocation compared to a situation (such as that prior to 1950) in which the unrelated business incomes of nonprofit organizations are entirely exempt from federal tax.

The fairness issue is extremely difficult to evaluate, due in large part to the absence of a consensus on what constitutes "unfair" commercial advantages. Rose-Ackerman (1982) argues that competition between taxable for-profit firms and tax-exempt nonprofits cannot, in equilibrium, be "unfair" to taxable competing firms, since all market participants must earn their required rates of return. While not conceding that the corporate tax discourages investment by taxable firms, Rose-Ackerman argues that, even if it does, the effect of exempting some but not all competitors from taxation is to increase the number of tax-exempt entities in the market without reducing the returns to taxable firms. This situation, she argues, is not "unfair" to taxable firms that choose to compete with tax-exempt entities, since such taxable firms must earn their required rates of return in expectation or else they would not compete in those markets.

This interpretation of fairness is not popular in certain industry circles and in some of the media coverage of this issue. ${ }^{4}$ There, the fairness issue is commonly coupled with the idea that tax-exempt competitors will be able to invest more, or to charge lower prices, or to provide better services at the same prices, than their taxable counterparts. Their ability to do so, so the argument goes, stems from the resources and the incentives generated by the tax exemption.

It is difficult to distinguish fairness concerns from efficiency issues in many of these controversies. Hansmann (1989) argues that fairness issues are secondary to issues of efficiency. The two are certainly related, in that the impact of the UBIT on both fairness and efficiency turn on its effect on the behavior of nonprofit organizations in commercial markets with taxable 
competitors.

Efficiency has the virtue of being (in principle) well defined, but its application to the analysis of the UBIT is greatly complicated by the $\mathrm{n}^{\text {th }}$ best nature of economies with multiple tax distortions. It is, however, straightforward to identify two issues related to the analysis of efficiency. The first is the effect of the tax exemption, and the UBIT, on the selection of commercial activities undertaken by nonprofit organizations. The second is the effect of the UBIT on managerial decisions in those unrelated business operations that nonprofits undertake.

For purposes of analysis, it is useful to consider the (counterfactual) case of a seamlessly enforced and operated UBIT that taxes only the unrelated portion (somehow defined) of a nonprofit organization's business income and does so without imposing any undue administrative or compliance costs. Nonprofit organizations have the opportunity to undertake any of a number of unrelated business operations. Suppose that nonprofit organizations do not have any special cost advantages over their taxable rivals, nor are they disadvantaged; they are on an equal footing except for any advantage conferred by their exemption from corporate income taxes. ${ }^{5}$

Rose-Ackerman (1982) makes the point that, if the alternative to investing in an unrelated business is instead to hold interest-bearing securities, then taxable and tax-exempt organizations will effectively face the same cost of capital when they invest in unrelated businesses, even in the absence of a UBIT. The opportunity cost of funds invested in business capital is the interest that could otherwise have been earned had the same money been used to buy bonds. For the purposes of this calculation it does not matter that tax-exempt organizations keep all of their returns while

\footnotetext{
${ }_{5}^{4}$ See, for example, Pound et al. (1995).

${ }^{5}$ The following analysis concerns only the effect of a nonprofit organization's exemption from the corporate income tax. The exemption from property, sales, and other taxes creates incentives to locate highly taxed activity in the nonprofit sector, as many observers have noted.
} 
taxable entities keep only a fraction, since each will invest in unrelated businesses only up to the point that they would not do better by purchasing bonds instead.

Hansmann (1989) notes that, in Rose-Ackerman's analysis, it is critical that the alternative to unrelated business investment is investment in interest-bearing securities (or other assets the returns to which are fully taxed when held by taxable investors). Hansmann compares the incentives to invest in unrelated businesses with those to hold corporate stock, and notes that the tax preference for unrealized capital gains on corporate stock implies that taxable investors will concentrate their investments in stock, while, in the absence of a UBIT, tax-exempt entities will concentrate their investments in business assets. Viewed differently, tax-exempt entities can avoid the corporate tax altogether by owning their business investments directly instead of holding 100 percent of the stock of taxpaying corporations. Taxable investors can also avoid the corporate tax by financing their investments entirely with debt, ${ }^{6}$ but Hansmann correctly observes that equity is also an important source of finance and it is therefore inappropriate to treat taxable investors as though they are untaxed on their corporate investments. Hansmann therefore concludes that the tax incentive for nonprofit organizations to invest in unrelated businesses creates an inefficiency that the UBIT serves to rectify.

Sansing (1998) calls attention to the importance of cost allocation to this analysis. If, in practice, nonprofit organizations are free to allocate as many of their general overhead costs as they wish against unrelated business income in calculating UBIT liabilities, then they will not face any tax obligations under the UBIT and the tax therefore fails to prevent the inefficiency noted by Hansmann. Sansing notes, however, that if instead a nonprofit faces important nondeductible costs of unrelated business activity - such as the cost to an organization's reputation, or its sense 
of mission, from excessive commercialization - then the UBIT may reduce efficiency by discouraging unrelated business activity that the organization would otherwise undertake. The inefficiency arises because the UBIT taxes the returns to unrelated business activity without allowing deductions for important nonpecuniary costs. Nonprofit organizations may well differ from ordinary businesses in their sensitivity to such costs.

Cordes and Weisbrod (1998) offer some evidence on this point from their examination of the information returns of a large sample of nonprofit organizations in 1992. They report that the ratio of public and private contributions received by a nonprofit organization is correlated with whether the organization has unrelated business income, interpreting this result to mean that public and private donors to nonprofit organizations are sensitive (indeed, differentially so) to the commercialization of their activities. Cordes and Weisbrod report a similar correlation between contribution sources and the fraction of total revenue accounted for by (tax-exempt) program service revenues, suggesting that it is not the "unrelatedness" of business income, but instead the commercialization of nonprofit activity, to which donors are sensitive. Cordes and Weisbrod also offer suggestive evidence that nonprofit organizations allocate internal costs in a manner that reduces their UBIT liabilities.

As most observers appear to agree, the effect of the UBIT on the efficiency of resource allocation is not so much a question of how nonprofit firms might manage any business operations that they run but instead one of the extent to which nonprofits choose to undertake unrelated business activity. Both Rose-Ackerman and Hansmann observe that nonprofits and for-profit firms face similar incentives to manage their business operations to maximize profits. Hansmann's main argument implies that a nonprofit organization might run an unrelated business somewhat

${ }^{6}$ As Stiglitz (1973) and others have noted. 
differently than would a for-profit firm, since the nonprofit has a lower cost of capital. But this implication is misleading, since the opportunity cost a nonprofit organization incurs by investing in a given unrelated business operation includes the cost of not investing in another. Consequently, if the nonprofit sector is small compared to the rest of the economy and therefore has access to an effectively limitless supply of potential unrelated business investment opportunities, the implicit cost of capital for any one business operation is the potential return elsewhere available, which must equal the pretax cost of funds for taxable investors. Nonprofit organizations therefore do not have tax incentives to manage their unrelated business operations any differently than do forprofit firms in the same lines of business.

There is an incentive for tax-exempt organizations to concentrate their investments in heavily-taxed assets, since equilibrium in a market dominated by taxable investors implies that such investments have the highest pre-tax returns. (This argument does not, of course, imply that investors will specialize completely, since such a strategy would generally conflict with diversification needs.) The UBIT therefore reduces the preference that nonprofits would otherwise have for business investments over ownership of corporate stock. But it does not follow that the UBIT enhances efficiency, quite apart from the scenario identified by Sansing. Corporate stock is not the only asset in which nonprofits invest; indeed, asset market equilibrium implies that corporate stock, which offers tax advantages to taxable investors, should carry a low pretax rate of return, and therefore will represent a relatively small fraction of the investment portfolio of tax-exempt entities. ${ }^{7}$ Nonprofit organizations have incentives to concentrate their

\footnotetext{
${ }^{7}$ Hilgert (1994, p. 102) reports that, as of yearend 1994, 501(c)(3) organizations had \$349 billion of (book) investments in securities (including stocks and corporate bonds), or $35 \%$ of their total (book) assets of $\$ 992$ billion. These book figures are likely to overstate the fraction of tradable securities in portfolios, but not all of the $\$ 992$ billion of assets are used for investment purposes.
} 
investments in bonds and other assets the returns of which are highly taxed - and that the market prices accordingly. Subjecting the unrelated business income of nonprofit organizations to the UBIT then serves to discourage unrelated business activity to an inefficient degree. In the absence of the UBIT, nonprofit organizations face the same incentives that taxable investors face in allocating funds between investments in bonds and investments in unrelated businesses. Introduction of the UBIT changes these incentives. Since nonprofit organizations invest in many asset types, with differing tax characteristics, a simple comparison of incentives to invest in corporate stock and incentives to invest in unrelated business assets is insufficient to evaluate the efficiency effects of the UBIT.

\section{Aggregate Patterns of Unrelated Business Income and UBIT}

This section considers the available aggregate evidence of the characteristics of unrelated business income earned by nonprofit organizations in recent years. This evidence is drawn from information provided to the Internal Revenue Service (IRS) on tax forms filed by nonprofits. Nonprofit organizations with gross unrelated business income of $\$ 1,000$ or more are required to file with the IRS Form 990-T, which is used to determine the size of any tax obligation the organization incurs on its unrelated business income. Form 990-T requires nonprofit organizations to report detailed information concerning their unrelated business activities. Since individual Form 990-T filings are confidential, it is not possible for researchers to analyze them directly; consequently, the only available Form 990-T information consists of national aggregates reported by the IRS on the basis of selected samples of Form 990-T filings. 
Table 1 summarizes recent experience with the UBIT in the United States. In 1994, 35,657 organizations filed Form 900-T. These organizations had total gross unrelated business income of $\$ 5.4$ billion, against which they claimed aggregate deductions of $\$ 6.5$ billion, for a net unrelated business loss of $\$ 1.1$ billion. Organizations exhibit considerable heterogeneity: the net incomes of the 18,588 organizations for which unrelated business income is positive sum to $\$ 643$ million (which therefore represents taxable profits), while the 17,070 organizations without positive unrelated business income had losses that sum to $\$ 1.77$ billion. Nonprofit organizations paid total UBIT of \$195 million in 1994.

While of unimpressive magnitude compared to other components of federal tax receipts, the $\$ 195$ million tax payment in 1994 reflects rapid recent growth in UBIT collections. Table 1 indicates that nonprofit organizations had UBIT obligations of only \$99.1 million in 1990, and that annual UBIT collections rose steadily between 1990 and 1994.

Entries in Table 1 describe the unrelated business income and UBIT of the entire nonprofit sector. Table 2 provides the same information for 1994, distinguishing organizations by the Internal Revenue Code sections under which they are tax exempt. As Table 2 indicates, 501(c)(3) organizations report more than half of aggregate gross unrelated business income in 1994 (\$3.1 billion out of a total of $\$ 5.4$ billion), and paid one-third of the total UBIT in that year. Other organizational types with gross unrelated business income exceeding \$200 million include 501(c)(4) organizations (civic leagues, social welfare organizations, and local associations of employees), 501(c)(6) organizations (business leagues, chambers of commerce, real estate boards, and like organizations), 501(c)(7) organizations (social and recreational clubs), and 501(c)(9) organizations (voluntary employees' beneficiary associations). 
The size and diversity of the 501(c)(3) population suggests that many different types of organizations within this category may earn unrelated business income. Table 3 presents a breakdown of unrelated business income and other financial information for differing types of 501(c)(3) organizations in 1993 (comparable figures being unavailable for 1994). The information presented in Table 3 was compiled by the IRS based on a matched sample of Form 990 and Form 990-T filings for 1993 (and reported in Riley, 1997). Form 990 is the information return that all nonprofits (other than religious organizations) are required to file annually with the IRS; they are public documents, and therefore are in principle available for researchers to use. The IRS selects for coding a sample of Form 990 filings stratified on asset size, with large organizations the most likely to be included in the sample.

The entries in Table 3 are based on information from organizations in the Form 990 sample that also file Form 990-T in 1993. Sampling weights used in the construction of the Form 990 sample are then inverted to generate the population estimates reported in Table 3. Since the sampling weights used to generate the numbers reported in Table 3 are not conditioned on earning unrelated business income (and therefore filing Form 990-T), inverting these weights does not, in general, produce accurate population estimates. For example, the estimated (based on sampling weights) 6,312 501(c)(3) organizations filing Form 990-T does not accord with the separately available (and more reliable) 1993 figure of 9,246. But patterns evident in Table 3 are likely to be reproduced in the population, since there is no particular reason that any biases introduced by inverting the sampling weights will differ systematically between types of 501(c)(3) organizations. The IRS adjusts income and expense items reported in Table 3 in order to make financial reporting entries (from Form 990) comparable with tax entries (reported on Form 990-T). 
Organizations are classified by type of activity, all but one of which is self-explanatory. A "publicly supported organization" must receive at least one-third of its total support from governmental units, from contributions made directly or indirectly by the general public, or from a combination of these sources; less than one-third of its funds may come from internal sources. Furthermore, "publicly supported organizations" are organized and operated in a manner to attract new and additional public or governmental support on a continuing basis.

The evidence reported in Table 3 indicates that the gross unrelated business income of 501(c)(3) organizations is a mere $1.1 \%$ of their total income, and that their unrelated business expenses are $1.1 \%$ of their total expenses. Net unrelated business income (gross income minus expenses) is therefore of trivial magnitude relative to other revenue sources. Hospitals account for roughly one-third of the unrelated business income of 501(c)(3) organizations, a sizable fraction but significantly less than their share of the 501(c)(3) sector's finances. Publiclysupported organizations, educational institutions, and organizations that support other charitable organizations also earn significant amounts of unrelated business income. ${ }^{8}$

Unrelated business income earned by nonprofit organizations in 1994 takes many forms, of which major categories are detailed in Table 4. Of the total unrelated business income of $\$ 5.4$ billion, half ( $\$ 2.7$ billion) consists of gross profit (less loss) from sales and services. Sales and services income is significant not only in terms of its aggregate level, but also in terms of the number of nonprofit organizations - 14,147 out of a total of 35,657 Form 990-T filers - reporting such income. Other important sources of unrelated business income include advertising income

\footnotetext{
${ }^{8}$ It is worth bearing in mind that the burden of the UBIT may be felt most keenly by organizations for whom the tax is so burdensome that they elect not to earn any unrelated business income and therefore do not appear in the figures reported in Table 3. Of course, it would be extremely difficult to estimate the distribution of such burdens across 501(c)(3) types.
} 
(\$943 million), other income (\$576 million), and various sources of investment income.

The available aggregate information indicates that the nonprofit sector's many sources of unrelated business income generate very little tax liability from the UBIT. Partly this reflects the fact that many organizations claim deductions against gross unrelated business income that are large enough to produce tax losses, but largely it reflects the absence of much unrelated business activity. While the reported figures do not include the operations of taxable subsidiaries, there is no evidence that this omission has a large effect on the aggregate numbers. ${ }^{9}$ The next section analyzes the characteristics of 501(c)(3) organizations with business operations that are unrelated to their exempt purposes.

\section{Who Has Unrelated Business Income?}

The behavior of nonprofit organizations that are subject to the UBIT reveals important information concerning their ability and willingness to earn unrelated business income in spite of the associated tax liability. This section analyzes information drawn from Form 990 filings of nonprofit organizations in 1989. These information returns do not contain any detail on a nonprofit organization's unrelated business income, nor do they indicate whether or not a nonprofit organization had positive UBIT liability in 1989. They do, however, have entries

\footnotetext{
${ }^{9}$ Prior to 1997 , any interest, rents, royalties, and annuities received from taxable subsidiaries owned at least $80 \%$ by parent nonprofit organizations were treated as unrelated business income and therefore taxable under the UBIT. The Taxpayer Relief Act of 1997 reduced the ownership share necessary for application of the UBIT to 50\% and introduced other changes intended to prevent tax avoidance through the use of subsidiaries of nonprofit organizations. The U.S. Congress, Joint Committee on Taxation (1997, pp. 239-240) estimates the revenue impact of these changes to be less than $\$ 5$ million per year, reflecting, in part, the modest volume of nonprofit business activity conducted through taxable subsidiaries.
} 
indicating whether the filing organization was also obliged to file Form 990-T for 1989, which is almost a perfect indicator of having gross unrelated business income in excess of $\$ 1,000$.

Consequently, it is possible to use publicly-available data reported on Form 990 to analyze the determinants of whether an organization has $\$ 1,000$ or more of gross unrelated business income.

\subsection{Unrelated Business Income of 501(c)(3)s.}

Table 5 presents the results of logit regressions in which the dependent variable equals one if an organization has gross unrelated business income greater than $\$ 1,000$ in 1989 , and equals zero otherwise. Independent variables include: book values of total assets at yearend 1989, administrative expenses in 1989, program service expenses in 1989, total expenses (defined as the sum of administrative and program service expenses), contributions received in 1989, government grants received in 1989, and total receipts (defined as the sum of contributions and government grants). Variable means and standard deviations are reported in Table 6. Independent variables are entered in log form; in some specifications, second and third powers of log assets are included as independent variables. ${ }^{10}$

Larger organizations are the most likely to report unrelated business income. The 0.2645 coefficient on $\log$ (Assets) in column one of Table 5 is large and differs significantly from zero. Evaluating the logit function at the sample mean of the independent variables, this coefficient implies that, as an organization's asset size doubles (and nothing else changes), it has 3.7\% greater likelihood of reporting unrelated business income. Since the sample mean likelihood of

\footnotetext{
${ }^{10}$ In order to prevent observations of very small nonprofits from exerting undue influence on the regression results, regression samples exclude the smallest (measured by yearend assets) $5 \%$ of the sample. Individual regressions exclude observations in which data are missing or independent variables (prior to logging) have values of less than $\$ 100$.
} 
reporting unrelated business income is $22 \%$, a difference of $3.7 \%$ is sizable.

The positive correlation between unrelated business income and asset size is not surprising. Quite apart from the factors that are idiosyncratic to unrelated business income, the larger an organization is, the more likely it is to have any given source of income. Size may also be correlated with other, unmeasured, characteristics that encourage organizations to earn unrelated business income, but these are inevitably very difficult to distinguish from the pure effect of organizational size. ${ }^{11}$

Conditioning on asset size, organizations with greater expenses, particularly servicerelated expenses, are more likely to have unrelated business income. The 0.4135 estimated coefficient on ln (Total Expense) in column one of Table 5 differs significantly from zero and implies that there is a positive correlation between total expenses and earning unrelated business income. Again evaluating the logit function at sample means, doubling an organization's service and administrative expenses (and holding other characteristics constant) is associated with 5.9\% greater likelihood of reporting gross unrelated business income. The regression reported in column two separates service expenses and administrative expenses; both are positively correlated with earning unrelated business income.

Organizations receiving high levels of contributions and government grants are less likely than are other organizations to report unrelated business income, conditional on asset size and other observable characteristics. While the estimated -0.0456 coefficient on $\ln$ (Total Receipts) in column one of Table 5 differs statistically from zero, it implies a smaller absolute effect on

\footnotetext{
${ }^{11}$ Another, possibly important, consideration is that large organizations may have the greatest ability to generate sizable deductions against gross unrelated business income through the allocation of joint costs. Adept cost allocation reduces the effective tax rate due to the UBIT, as Sansing (1998) notes.
} 
unrelated business income than do the estimated coefficients on total assets and total expenses reflecting, in part, the smaller magnitude of receipts from contributions and government grants. Evaluating the logit function at sample means, $100 \%$ higher total receipts are associated with $0.6 \%$ lower likelihood of reporting unrelated business income. The specifications reported in columns three and five provide estimates of separate effects of contributions and government grants, doing so from a sample consisting of organizations that report both contributions and government grants in excess of $\$ 100$. In this sample of 2,891 organizations, contributions have an insignificant effect on unrelated business income, while government grants have a significant negative effect.

One of the difficulties of interpreting the evidence reported in the first three columns of Table 5 comes from the fact that several of the independent variables represent differing measures of an organization's size. To be sure, the inclusion of log assets as a regressor means that the effects of other variables are measured in a way that is conditioned on the size of an organization's assets, but there remains the possibility that estimated coefficients on variables other than assets reflect nonlinearities in the effect of organizational size on unrelated business income. The regressions reported in columns four and five of Table 5 include as regressors three powers of $\log$ assets in order to absorb the effects of simple nonlinearities. The results are quite consistent with those reported in columns one through three.

The regressions reported in Table 5 indicate that large organizations with many expenses and few receipts of contributions and government grants are the most likely to report earning unrelated business income in 1989. This pattern is consistent with a preference on the part of 501(c)(3) organizations not to divert their energies into earning unrelated business income, but a 
willingness to do so when feeling financial pressure from ongoing operations. An alternate interpretation of the evidence is that organizations earning unrelated business income spend more and attract fewer contributions and government grants than do other organizations. And a third possibility is simply that organizations differ in their opportunities to earn business income; that such opportunities appear most often among organizations with many expenses and few receipts of contributions and government grants. In order to distinguish between these interpretations of the regressions reported in Table 5, it is useful to juxtapose this evidence with similar regressions in which the dependent variable indicates whether an organization has business income coming from sources that are "related" to exempt purposes.

\subsection{Inventory Sales by 501(c)(3)s.}

Nonprofit organizations often supplement their revenues with membership dues, rental income, income from special events and activities, and profits from sales of inventory items. Of these, sales of inventory items are the most likely to require organizations to have financial and commercial infrastructure and to reflect business opportunities available to nonprofit organizations. Sales of inventory items need not constitute unrelated business income; in the sample of organizations analyzed in Table 5, only $31 \%$ of those reporting gross profits of $\$ 1,000$ or more from sales of inventory items also report gross unrelated business income of $\$ 1,000$ or more (from all sources). For the economy as a whole in 1994, 501(c)(3) organizations report inventory sales of $\$ 7.2$ billion, on which they earned $\$ 3.2$ billion of gross profit. ${ }^{12}$ Sales of inventory items typically do not constitute unrelated business income, and inventory sales exceed total unrelated business income in the 501(c)(3) sector. 
Table 7 reports the results of regressions in which the dependent variable is a dummy variable that takes the value one if a 501(c)(3) organization has at least $\$ 1,000$ of gross profits from sales of inventory items in 1989, and equals zero otherwise. Estimated coefficients in these logit regressions differ in sign and magnitude from the coefficients (reported in Table 5) estimated for unrelated business income. Greater asset size is associated with higher likelihood of reporting profits from inventory sales, but the effect of asset size is insignificant in all but the regression reported in column three. More striking is the sign pattern of estimated coefficients on expense and receipt items. Organizations with greater expenses, particularly program service expenses, are less likely than others to report earning profits from inventory sales, while organizations with greater receipts of contributions and government grants, particularly contributions, are more likely than others to report earning profits from inventory sales.

These patterns differ sharply from those reported in Table 5. They suggest that the organizational characteristics associated with earning unrelated business income reflect something other than simple business opportunities, or at least those that are expressed by selling inventory items. Suppose that the unobserved characteristics of an organization that are correlated with earning unrelated business income are also correlated with asset size and total expenses, and are negatively correlated with receipts of contributions and government grants. If so, then the estimated coefficients reported in Table 5 reflect nothing of a causal nature but instead spurious correlations. If the same unobserved characteristics are also correlated with earning profits from sales of inventory items, then the sign pattern reported in Table 5 should also appear in Table 7 but it does not.

The issue of unobserved organizational characteristics suggests a related but more

\footnotetext{
${ }^{12}$ See Hilgert (1998, p. 104).
} 
powerful test of the effect of various independent variables on whether an organization earns unrelated business income or profits from inventory sales. Table 8 classifies the large sample of 8,594 organizations by whether or not they have unrelated business income and whether or not they have gross profits from sales of inventory items. In this sample, 5,837 organizations report neither type of income, while 379 report both. Of particular interest are the 2,378 organizations reporting either unrelated business income, or gross sales profits, but not both. These 2,378 organizations share the characteristic of being able and willing to generate income with business activity, but they differ in the type of activity they undertake. It is possible to use this sample to estimate the determinants of reporting one type of income and not the other.

Table 9 reports the results of logit regressions in which the dependent variable equals one if an organization has unrelated business income but no sales profits, and equals zero if an organization has no unrelated business income but positive sales profits. The sample consists of the 2,378 observations with either unrelated business income or profits from sales in $1989 .{ }^{13}$

The results reported in Table 9 are quite consistent with those reported in Tables 5 and 7 . Organizations with greater expenses, particularly service expenses, are more likely than others to report unrelated business income rather than profits from sales of "related" inventory.

Contributions and government grants reduce the likelihood that an organization will report unrelated business income instead of profits from sales of "related" inventory.

\subsection{Hospitals.}

The 501(c)(3) category encompasses an extremely heterogeneous group of nonprofit

\footnotetext{
${ }^{13}$ Chamberlain (1980) discusses the properties of the fixed effects logit estimator in panel estimation, which is adapted to the current cross-sectional application.
} 
organizations, making it a challenge to generalize about their motives and also making it difficult to rule out the possibility that unobserved heterogeneity is responsible for the patterns that are evident in the regressions. While it is possible to classify nonprofit organizations by their primary activities, and analyze each organizational type separately, doing so greatly reduces the statistical power of the estimates - and does not solve all of the problems raised by organizational heterogeneity. Since the sample is stratified on asset size, hospitals are sufficiently well represented in the sample (2,173 of the 8,594 observations) to afford reliable estimation of coefficients exclusively from the hospital subsample. The advantage of estimating the regressions on only the hospital subsample is that the resulting coefficients are thereby less likely to reflect any spurious correlations induced by organizational heterogeneity.

Table 10 presents estimated coefficients from regressions that are identical to those reported in Table 5 but that are run only on observations of 501(c)(3) hospitals. The coefficient pattern is remarkably similar to that reported in Table 5. Asset size is positively correlated with reporting unrelated business income, as is total expenses, particularly service expenses. Receipt of contributions and government grants, particularly government grants, is negatively associated with reporting unrelated business income. Nonprofit hospitals are the subject of extensive research that is largely devoted to identifying any differences between their behavior and the behavior of for-profit, taxable, hospitals. ${ }^{14}$ The evidence reported in Tables 5 and 10 suggests that the financial determinants of unrelated business activity by nonprofit hospitals are similar to those that affect nonprofit organizations outside of the health area.

\subsection{Implications.}


The estimation results are consistent with the interpretation that nonprofit organizations prefer not to engage in unrelated business activities, but do so if they feel pressing needs for additional sources of finance. There are other possible interpretations of the evidence, but none that accord consistently with the patterns of behavior evident in the data.

Since the financial constraints facing nonprofit organizations are, to one degree or another, under the control of those organizations, it is possible that organizations flush with cash from unrelated business activities spend their cash on program-related services and in failing to pursue sources of contributions and government grants. There are two reasons why it is unlikely that the direction of causality works in this way. First, the aggregate figures make it clear that unrelated business income cannot have a major impact on organizational finances even under the best of circumstances; gross unrelated business revenues are just too small for that. Unrelated business activities instead represent one component of what are likely to be more comprehensive efforts to strengthen the finances of organizations in financial need. Second, if income generated by unrelated business activity has a major impact on spending and on the pursuit of contributions and government grants, then it is difficult to understand why the same is not true of income generated by sales of inventory items.

Another possibility is that the estimated coefficients reflect nothing more than reporting behavior on the part of nonprofit organizations. Since unrelated business income is self-reported, and since nonprofit organizations are virtually never audited by the IRS, organizations have incentives to misreport any otherwise-taxable activities as being either related to charitable purpose, and therefore exempt from tax, or else unprofitable due to large deductions from income. The difficulty with this interpretation is that reporting considerations should generally

${ }^{14}$ See Sloan (1998) for a recent survey. 
bias against finding the results presented in Tables 5-10, since organizations with pressing financial needs are the least likely to reveal to the IRS that they earn unrelated business income. To be sure, once gross unrelated business income is reported, threadbare organizations have strong incentives to overstate - or to interpret generously - any available deductions against that income. Indeed, it may be the coincidence of financial need and unrelated business income that is responsible for the (reported) unprofitability of aggregate unrelated business activity in the aggregate statistics.

The evidence suggests that the burden of the UBIT falls most heavily on organizations with the greatest financial need. There is more than one way to view such incidence. One view is that subjecting such organizations to the UBIT hinders their attempts to obtain needed funds to further their exempt purposes. Another view is that organizations with great financial needs are those that spend beyond their means or are unable to attract public contributions or government grants. Evaluations of the UBIT turn largely on the organizational attributes that are associated with earning unrelated business income, and about these we have only indirect evidence. 


\section{Conclusion}

The Unrelated Business Income Tax raises very little direct revenue for the federal government, but serves the function of discouraging most nonprofit organizations from undertaking unrelated business activity. The evidence from information returns filed with the IRS suggests that 501(c)(3) organizations are generally reluctant to engage in unrelated business activity, typically doing so when pressed by strong financial needs. This reluctance on the part of 501(c)(3) organizations reflects their own perceptions of the costliness of diverting organizational focus from charitable activities, as well as the cost of possibly alienating employees, contributors, and other supporters. The general unwillingness of nonprofit organizations to undertake unrelated business activity is an important consideration in evaluating whether the UBIT is necessary in order to prevent "unfair" competition between nonprofits and for-profit firms. In addition, the inability of nonprofit organizations to deduct from taxable income the special organizational costs they incur in earning unrelated business income implies that the UBIT may reduce the efficiency of resource allocation. 


\section{References}

Bitker, Boris I. and George K. Radhert, The exemption of nonprofit organizations from federal income taxation, Yale Law Journal, January 1976, 85 (3), 299-358.

Chamberlain, Gary, Analysis of covariance with qualitative data, Review of Economic Studies, January 1980, 47 (1), 225-238.

Cordes, Joseph J. and Burton A. Weisbrod, Differential taxation of nonprofits and the commercialization of nonprofit revenues, Journal of Policy Analysis and Management, Spring 1998, 17 (2), 195-214.

Hansmann, Henry, Unfair competition and the Unrelated Business Income Tax, Virginia Law Review, April 1989, 75 (3), 605-634.

Hilgert, Cecelia, Charities and other tax-exempt organizations, 1994, SOI Bulletin, Spring 1998, 17 (4), 89-110.

Pound, Edward T., Gary Cohen, and Penny Loeb, Tax exempt!, U.S. News and World Report, October 2, 1995, 119 (13), 36-51.

Riley, Margaret, Exempt organization business income tax returns, 1991, SOI Bulletin, Spring 1995, 14 (4), 38-63.

Riley, Margaret, Exempt organization business income tax returns: Highlights and an analysis of exempt and nonexempt finances, 1993, SOI Bulletin, Spring 1997, 16 (4), 75-98.

Riley, Margaret, Unrelated business income of nonprofit organizations, 1994, SOI Bulletin, Spring 1998, 17 (4), 111-132.

Rose-Ackerman, Susan, Unfair competition and corporate income taxation, Stanford Law Review, May 1982, 34 (5), 1017-1039.

Sansing, Richard, The Unrelated Business Income Tax, cost allocation, and productive efficiency, National Tax Journal, June 1998, 51 (2), 291-302.

Simon, John, The tax treatment of nonprofit organizations: A review of federal and state policies, in: Walter W. Powell, ed. The nonprofit sector: A research handbook (New Haven, CT: Yale University Press, 1987), 67-98.

Sloan, Frank A., Commercialism in nonprofit hospitals, Journal of Policy Analysis and Management, Spring 1998, 17 (2), 234-252. 
Stiglitz, Joseph E., Taxation, corporate financial policy, and the cost of capital, Journal of Public Economics, 2 (1), 1-34.

United States Congress, Joint Committee on Taxation, General explanation of tax legislation enacted in 1997 (Washington, DC: U.S. Government Printing Office, 1997).

United States General Accounting Office, Competition between taxable businesses and taxexempt organizations, Briefing report to the Joint Committee on Taxation, U.S. Congress, No. GAO/GGD-87-40BR, February 1987. 


\begin{tabular}{|c|c|c|c|c|c|}
\hline \multicolumn{7}{|c|}{ Table 1 } \\
Unrelated Business Income and UBIT, 1990-1994 \\
\hline Year & 1990 & 1991 & 1992 & 1993 & 1994 \\
\hline $\begin{array}{c}\text { Number of Returns } \\
\text { Gross Unrelated Business Income } \\
\text { (\$ millions) }\end{array}$ & 31,091 & 32,690 & 31,122 & 32,638 & 35,657 \\
\hline $\begin{array}{c}\text { Total Deductions } \\
\text { (\$ millions) }\end{array}$ & $4,143.1$ & $4,047.2$ & $5,182.6$ & $5,741.4$ & $6,506.8$ \\
\hline $\begin{array}{c}\text { Net Income (less deficit) } \\
\text { \$ millions) }\end{array}$ & -631.6 & -662.5 & $-1,113.4$ & $-1,047.2$ & $-1,127.0$ \\
\hline $\begin{array}{c}\text { Net Income } \\
\text { (taxable profit) }\end{array}$ & 388.9 & 431.1 & 485.9 & 603.6 & 643.0 \\
\cline { 2 - 7 } \\
$\begin{array}{c}\text { Of which: } \\
\text { \$ millions) }\end{array}$
\end{tabular}

Note to Table 1: The table entries are population estimates for all U.S. exempt organizations drawn from Form 990-T filings between 1990 and 1994. "Net income (less deficit)" is the difference between gross unrelated business income and deductions claimed against unrelated business income. "Net income (taxable profit)" corresponds to the difference between gross unrelated business income and deductions for all exempt organizations for which this difference is positive. "Deficit" corresponds to the difference between gross unrelated business income and deductions for all exempt organizations for which this difference is negative. Dollar figures are millions of current dollars.

Source: Riley (1995, 1997, 1998). 


\section{Table 2}

\section{Unrelated Business Income, and UBIT, by Type of Tax-Exempt Organization, 1994}

\begin{tabular}{|c|c|c|c|c|c|c|c|}
\hline \multirow{2}{*}{$\begin{array}{c}\text { Internal } \\
\text { Revenue } \\
\text { Code } \\
\text { Section }\end{array}$} & \multirow{2}{*}{$\begin{array}{l}\text { Number of } \\
\text { Returns }\end{array}$} & \multirow{2}{*}{$\begin{array}{c}\text { Gross } \\
\text { Unrelated } \\
\text { Business } \\
\text { Income (\$) }\end{array}$} & \multirow{2}{*}{$\begin{array}{c}\text { Total } \\
\text { Deduc- } \\
\text { tions } \\
(\$)\end{array}$} & \multirow{2}{*}{$\begin{array}{c}\text { Net } \\
\text { income } \\
\text { (less } \\
\text { deficit) }(\$)\end{array}$} & \multirow{2}{*}{$\begin{array}{l}\text { Deficit } \\
(\$)\end{array}$} & \multicolumn{2}{|c|}{ Total Income Tax } \\
\hline & & & & & & $\begin{array}{c}\text { Number of } \\
\text { Returns }\end{array}$ & $\begin{array}{c}\text { Amount } \\
(\$)\end{array}$ \\
\hline Total & 35,657 & $5,379,838$ & $6,506,838$ & $-1,127,001$ & $-1,769,954$ & 18,594 & 195,191 \\
\hline 401(a) & 988 & 124,603 & 35,734 & 88,869 & $-12,886$ & 875 & 34,325 \\
\hline 408(e) & 5,330 & 30,518 & 20, & 10,184 & $-4,466$ & 5,043 & 4,025 \\
\hline $501(\mathrm{c})(2)$ & 182 & 44,9 & 103,917 & $-58,960$ & $-61,167$ & 97 & 611 \\
\hline $501(\mathrm{c})(3)$ & 9,277 & $3,119,920$ & $4,075,056$ & $-955,136$ & $-1,174,048$ & 2,967 & 64,695 \\
\hline $501(\mathrm{c})(4)$ & 1,498 & 249,859 & 290,072 & $-40,213$ & $-55,065$ & 579 & 3,888 \\
\hline $501(\mathrm{c})(5)$ & 2,625 & 193,605 & 263,804 & $-70,200$ & $-92,271$ & 1,120 & 5,465 \\
\hline $501(c)(6)$ & 5,962 & 70 & 867 & -163 & $-217,972$ & 2,023 & 18,207 \\
\hline $501(\mathrm{c})(7$ & 6,447 & 35 & 364 & -8 & $-70,552$ & 4,530 & 12,927 \\
\hline $501(\mathrm{c})(8$ & 929 & 89 & 72, & -18 & $-24,666$ & 392 & 814 \\
\hline $501(\mathrm{c})(9)$ & 653 & 271,125 & 157,928 & 113,197 & $-9,550$ & 362 & 43,403 \\
\hline $501(\mathrm{c})(10)$ & 251 & 10,620 & 11,986 & $-1,366$ & $-2,581$ & 108 & 219 \\
\hline $501(\mathrm{c})(12)$ & 118 & 13,551 & 14,192 & -641 & $-4,431$ & 63 & 899 \\
\hline 501(c)(13) & 32 & 2,011 & 2,025 & -14 & 31 & 4 & 3 \\
\hline 501(c)(14) & 73 & 8,089 & 11,075 & $-2,986$ & $-3,456$ & 61 & 70 \\
\hline 501(c)(19) & 1,281 & 110,992 & 137,366 & $-26,374$ & $-32,239$ & 357 & 1,051 \\
\hline
\end{tabular}

Note to Table 2: The table presents information on the unrelated business income of organizations exempt from federal income tax in 1994; "Number of returns" indicates the number of organizations filing Form 990-T, the Exempt Organization Business Income Tax return. "Gross unrelated business income" is income before deductions, and "Total Deductions" are deductions claimed against unrelated business income; "Net income" is the difference between gross income and total deductions. "Deficit" is the total net income of only those organizations with negative net income. Entries in the last two columns - number of tax returns and amount of total income tax describe those organizations filing Form 990-T and paying positive UBIT in 1994. Dollar amounts are thousands of current dollars.

IRS code section numbers correspond to the following types of organizations: 401(a): qualified pension, profitsharing, or stock bonus plans; 408(e): individual retirement arrangements; 501(c)(2): title-holding corporations for exempt organizations; 501(c)(3): religious, educational, charitable, scientific, or literary organizations, organizations preventing cruelty to children, or fostering national or international amateur sports competition; 501(c)(4): civic leagues, social welfare organizations, and local associations of employees; 501(c)(5): labor, agricultural, and horticultural organizations; 501(c)(6): business leagues, chambers of commerce, real estate boards, and like organizations; 501(c)(7): social and recreational clubs; 501(c)(8): fraternal beneficiary societies and associations; 501(c)(9): voluntary employees' beneficiary associations; 501(c)(10): domestic fraternal societies and associations; 501(c)(12): benevolent life insurance associations, mutual ditch or irrigation companies, mutual or cooperative telephone companies, and like organizations; 501(c)(13): cemetery companies; 501(c)(14): statechartered credit unions and mutual reserve funds; 501(c)(19): posts or organizations of past or present members of the armed forces.

Source: Riley (1998). 


\section{Table 3}

\section{Income, Expenses and Unrelated Business Income of 501(c)(3) Organizations, Matched Sample, 1993}

\begin{tabular}{|c|c|c|c|c|c|}
\hline $\begin{array}{c}\text { Type of 501(c)(3) } \\
\text { Organization }\end{array}$ & $\begin{array}{c}\text { Number of } \\
\text { Returns }\end{array}$ & $\begin{array}{c}\text { Adjusted } \\
\text { Total Income } \\
\text { (\$ millions) }\end{array}$ & $\begin{array}{c}\text { Adjusted } \\
\text { Total } \\
\text { Expenses } \\
\\
\text { (\$ millions) } \\
\end{array}$ & $\begin{array}{c}\text { Adjusted } \\
\text { Unrelated } \\
\text { Business } \\
\text { Income } \\
\text { (\$ millions) } \\
\end{array}$ & $\begin{array}{l}\text { Adjusted } \\
\text { Unrelated } \\
\text { Business } \\
\text { Expenses } \\
\text { (\$ millions) } \\
\end{array}$ \\
\hline Total & 6,312 & $\$ 222,654$ & $\$ 233,513$ & $\$ 2,435$ & $\$ 2,447$ \\
\hline $\begin{array}{c}\text { Educational institution or } \\
\text { school }\end{array}$ & 533 & 39,577 & 41,173 & 228 & 220 \\
\hline Hospital & 1,159 & 140,022 & 135,379 & 848 & 924 \\
\hline $\begin{array}{c}\text { Hospital research } \\
\text { organization }\end{array}$ & 5 & 1,447 & 1,179 & 5 & 5 \\
\hline $\begin{array}{c}\text { Organization supporting a } \\
\text { public college }\end{array}$ & 173 & 616 & 736 & 30 & 30 \\
\hline $\begin{array}{c}\text { Organization supporting } \\
\text { other charitable } \\
\text { organizations }\end{array}$ & 301 & 14,222 & 13,801 & 438 & 373 \\
\hline $\begin{array}{c}\text { Publicly-supported } \\
\text { organization }\end{array}$ & 4,132 & 25,9000 & 30,389 & 883 & 892 \\
\hline Other & 9 & 871 & 857 & 4 & 3 \\
\hline
\end{tabular}

Note to Table 3: The table presents information from a matched (stratified) sample of Form 990 and Form 990-T filings by 501(c)(3) organizations for 1993. Data from only those organizations that are included in the stratified sample, and that file both Form 990 and Form 990-T, are the basis of the figures in the table; sampling weights are used to construct population estimates. Income and expense items reported in the table are adjusted by the IRS to make financial reporting entries (from Form 990) comparable with tax entries (reported on From 990-T). Dollar amounts are millions of current dollars.

Organizations are classified by type of activity; a "publicly-supported organization" must receive at least one third of its total support from governmental units, from contributions made directly or indirectly by the general public, or from a combination of these sources; less than one-third of its funds may come from internal sources. "Publiclysupported organizations" are organized and operated in a manner to attract new and additional public or governmental support on a continuous basis.

Source: Riley (1997). 


\section{Table 4}

\section{Source of Gross Unrelated Business Income, 1994}

\begin{tabular}{|l|r|r|}
\hline \multicolumn{1}{|c|}{ Income Item } & \multicolumn{1}{c|}{$\begin{array}{c}\text { Amount } \\
\text { (\$thousands) }\end{array}$} & $\begin{array}{c}\text { Number of Organizations } \\
\text { Reporting }\end{array}$ \\
\hline Total & $\$ 5,379,838$ & 35,657 \\
\hline Gross profit (less loss) from sales and services & $2,700,302$ & 14,147 \\
\hline Capital gain net income & 144,612 & 513 \\
\hline Net capital loss (trusts only) & -242 & 78 \\
\hline Net gain (less loss), sales of noncapital assets & 3,644 & 309 \\
\hline Income (less loss) from partnerships & 134,379 & 6,295 \\
\hline Rental income & 120,912 & 3,722 \\
\hline Unrelated debt-financed income & 347,868 & 2,358 \\
\hline Investment income (less loss) & 274,450 & 5,556 \\
\hline Income from controlled organizations & 45,506 & 1,376 \\
\hline Exploited exempt activity income, except advertising & 89,535 & 801 \\
\hline Advertising income & 942,711 & 7,582 \\
\hline Other income (less loss) & 576,161 & 6,333 \\
\hline
\end{tabular}

Note to Table 4: The table distinguishes sources of unrelated business income reported by all nonprofit organizations filing Form 990-T in 1994. Income items reported in Table 4 are gross of various deductions claimed on Form 990-T. Dollar amounts are thousands of current dollars.

Source: Riley (1998). 
Table 5

\section{Unrelated Business Income of 501(c)(3)s, 1989}

Dependent variable equals one if an organization reports unrelated business income for 1989, and equals zero otherwise.

\begin{tabular}{|c|c|c|c|c|c|}
\hline Constant & $\begin{array}{r}-11.7327 \\
(0.3681)\end{array}$ & $\begin{array}{r}-11.2206 \\
(0.3868)\end{array}$ & $\begin{array}{r}-11.3168 \\
(0.5942)\end{array}$ & $\begin{array}{c}-9.9958 \\
(12.9293)\end{array}$ & $\begin{array}{l}-26.8112 \\
(22.3267)\end{array}$ \\
\hline ln Assets & $\begin{array}{c}0.2645 \\
(0.0351) \\
\end{array}$ & $\begin{array}{c}0.2507 \\
(0.0374) \\
\end{array}$ & $\begin{array}{c}0.4215 \\
(0.0635) \\
\end{array}$ & $\begin{array}{c}0.2181 \\
(2.3910) \\
\end{array}$ & $\begin{array}{c}3.3733 \\
(4.0332) \\
\end{array}$ \\
\hline$(\ln \text { Assets })^{2}$ & & & & $\begin{array}{l}-0.0087 \\
(0.1465)\end{array}$ & $\begin{array}{l}-0.1842 \\
(0.2414)\end{array}$ \\
\hline$(\ln \text { Assets })^{3}$ & & & & $\begin{array}{c}0.0004 \\
(0.0030) \\
\end{array}$ & $\begin{array}{c}0.0038 \\
(0.0048) \\
\end{array}$ \\
\hline ln Total Expense & $\begin{array}{c}0.4135 \\
(0.0294)\end{array}$ & & & & \\
\hline In Service Expense & & $\begin{array}{c}0.2298 \\
(0.0350) \\
\end{array}$ & $\begin{array}{c}0.1994 \\
(0.0573) \\
\end{array}$ & $\begin{array}{c}0.2255 \\
(0.0352) \\
\end{array}$ & $\begin{array}{c}0.1977 \\
(0.0576) \\
\end{array}$ \\
\hline In Admin. Expense & & $\begin{array}{c}0.1860 \\
(0.0285) \\
\end{array}$ & $\begin{array}{c}0.0799 \\
(0.0468) \\
\end{array}$ & $\begin{array}{c}0.1875 \\
(0.0286) \\
\end{array}$ & $\begin{array}{c}0.0826 \\
(0.0469) \\
\end{array}$ \\
\hline ln Total Receipts & $\begin{array}{l}-0.0456 \\
(0.0124) \\
\end{array}$ & $\begin{array}{c}-0.0364 \\
(0.0133) \\
\end{array}$ & & $\begin{array}{c}-0.0384 \\
(0.0134) \\
\end{array}$ & \\
\hline In Contributions & & & $\begin{array}{c}0.0071 \\
(0.0270) \\
\end{array}$ & & $\begin{array}{c}0.0057 \\
(0.0270)\end{array}$ \\
\hline ln Grants & & & $\begin{array}{l}-0.1002 \\
(0.0253)\end{array}$ & & $\begin{array}{l}-0.1036 \\
(0.0256)\end{array}$ \\
\hline In Likelihood & -3761.5 & -3378.9 & -1430.3 & -3378.2 & -1429.8 \\
\hline $\begin{array}{c}\text { Number of } \\
\text { observations }\end{array}$ & 8,594 & 7,483 & 2,891 & 7,483 & 2,891 \\
\hline
\end{tabular}

Note to Table 5: The columns report coefficients from logit regressions in which the dependent variable equals one if a 501(c)(3) organization has unrelated business income greater than $\$ 1,000$ in 1989, and equals zero otherwise. "Assets" equal the gross book value of yearend 1989 assets; "Total Expense" equals the sum of administrative and service expenses; "Total Receipts" equals the sum of contributions and grants. Regression samples exclude organizations with asset sizes below the fifth percentile of the sample, and those observations in which any independent variable (prior to taking logs) is less than \$100. All variables are measured in 1989 dollars. Standard errors are in parentheses. 


\begin{tabular}{|c|c|c|c|c|}
\hline \multicolumn{5}{|c|}{$\begin{array}{c}\text { Table } 6 \\
\text { Means and Standard Deviations of Regression Variables }\end{array}$} \\
\hline \multirow{10}{*}{$\begin{array}{l}1989 \text { large sample } \\
\text { (Tables } 5 \text { and 7) }\end{array}$} & Variable & Mean & $\begin{array}{l}\text { Standard } \\
\text { deviation }\end{array}$ & $\begin{array}{c}\text { Number of } \\
\text { observations }\end{array}$ \\
\hline & $\begin{array}{c}\text { Unrelated } \\
\text { business income } \\
\text { dummy }\end{array}$ & 0.2219 & 0.4155 & 8594 \\
\hline & $\begin{array}{l}\text { Inventory sales } \\
\text { dummy }\end{array}$ & 0.1430 & 0.3501 & 8594 \\
\hline & ln Assets & 16.2594 & 1.9587 & 8594 \\
\hline & ln Total Expense & 15.4143 & 2.1719 & 8594 \\
\hline & ln Total Receipts & 13.1712 & 2.3468 & 8594 \\
\hline & $\begin{array}{c}\text { ln Service } \\
\text { Expense }\end{array}$ & 15.7577 & 1.9665 & 2891 \\
\hline & $\begin{array}{l}\text { ln Admin. } \\
\text { Expense }\end{array}$ & 14.0580 & 1.9075 & 2891 \\
\hline & ln Contributions & 13.5332 & 2.1840 & 2891 \\
\hline & ln Grants & 13.1041 & 2.1202 & 2891 \\
\hline \multirow{8}{*}{$\begin{array}{l}1989 \text { sample of } \\
\text { organizations with } \\
\text { either unrelated } \\
\text { business income or } \\
\text { profits from inventory } \\
\text { sales but not both } \\
\text { (Table 9) }\end{array}$} & $\begin{array}{l}\text { Unrelated } \\
\text { business income } \\
\text { vs. inventory } \\
\text { sales dummy }\end{array}$ & 0.6426 & 0.4793 & 2378 \\
\hline & $\ln$ Assets & 16.9486 & 1.8118 & 2378 \\
\hline & ln Total Expense & 16.2802 & 1.9973 & 2378 \\
\hline & ln Total Receipts & 13.4482 & 2.2969 & 2378 \\
\hline & $\begin{array}{c}\text { ln Service } \\
\text { Expense }\end{array}$ & 16.2892 & 1.8785 & 982 \\
\hline & $\begin{array}{l}\text { ln Admin. } \\
\text { Expense }\end{array}$ & 14.5835 & 1.7367 & 982 \\
\hline & $\ln$ Contributions & 13.9045 & 2.0219 & 982 \\
\hline & ln Grants & 13.2473 & 2.1156 & 982 \\
\hline \multirow{8}{*}{$\begin{array}{l}1989 \text { hospital sample } \\
\text { (Table 10) }\end{array}$} & $\begin{array}{c}\text { Unrelated } \\
\text { business income } \\
\text { dummy }\end{array}$ & 0.4050 & 0.4910 & 2173 \\
\hline & $\ln$ Assets & 17.4781 & 1.2322 & 2173 \\
\hline & ln Total Expense & 17.3298 & 1.3622 & 2173 \\
\hline & ln Total Receipts & 12.1323 & 2.1534 & 2173 \\
\hline & $\begin{array}{l}\text { ln Service } \\
\text { Expense }\end{array}$ & 17.6180 & 1.3023 & 512 \\
\hline & $\begin{array}{l}\text { ln Admin. } \\
\text { Expense }\end{array}$ & 15.8915 & 1.4027 & 512 \\
\hline & ln Contributions & 12.5488 & 2.0807 & 512 \\
\hline & ln Grants & 12.5283 & 2.0173 & 512 \\
\hline
\end{tabular}




\section{Table 7}

\section{Profits from Inventory Sales by 501(c)(3)s, 1989}

Dependent variable equals one if an organization reports profits from inventory sales in 1989, and equals zero otherwise.

\begin{tabular}{|c|c|c|c|c|c|}
\hline Constant & $\begin{array}{l}-3.1980 \\
(0.2773)\end{array}$ & $\begin{array}{l}-3.0710 \\
(0.2992) \\
\end{array}$ & $\begin{array}{c}-3.3026 \\
(0.4578) \\
\end{array}$ & $\begin{array}{c}-7.2036 \\
(8.1381) \\
\end{array}$ & $\begin{array}{l}-13.2321 \\
(13.9001)\end{array}$ \\
\hline ln Assets & $\begin{array}{c}0.0203 \\
(0.0281)\end{array}$ & $\begin{array}{c}0.0535 \\
(0.0312)\end{array}$ & $\begin{array}{c}0.4060 \\
(0.0563)\end{array}$ & $\begin{array}{c}0.9967 \\
(1.5467) \\
\end{array}$ & $\begin{array}{c}2.1491 \\
(2.5818)\end{array}$ \\
\hline$(\ln \text { Assets })^{2}$ & & & & $\begin{array}{l}-0.0680 \\
(0.0970)\end{array}$ & $\begin{array}{l}-0.1009 \\
(0.1583)\end{array}$ \\
\hline$(\ln \text { Assets })^{3}$ & & & & $\begin{array}{c}0.0016 \\
(0.0020)\end{array}$ & $\begin{array}{c}0.0019 \\
(0.0032)\end{array}$ \\
\hline ln Total Expense & $\begin{array}{l}-0.0369 \\
(0.0247) \\
\end{array}$ & & & & \\
\hline In Service Expense & & $\begin{array}{l}-0.2509 \\
(0.0306)\end{array}$ & $\begin{array}{l}-0.4307 \\
(0.0535)\end{array}$ & $\begin{array}{c}-0.2557 \\
(0.0308)\end{array}$ & $\begin{array}{l}-0.4240 \\
(0.0540)\end{array}$ \\
\hline ln Admin. Expense & & $\begin{array}{c}0.1790 \\
(0.0293) \\
\end{array}$ & $\begin{array}{c}0.0430 \\
(0.0471)\end{array}$ & $\begin{array}{c}0.1801 \\
(0.0293)\end{array}$ & $\begin{array}{c}0.0431 \\
(0.0474)\end{array}$ \\
\hline ln Total Receipts & $\begin{array}{c}0.1229 \\
(0.0156)\end{array}$ & $\begin{array}{c}0.1386 \\
(0.0171)\end{array}$ & & $\begin{array}{c}0.1360 \\
(0.0171)\end{array}$ & \\
\hline In Contributions & & & $\begin{array}{c}0.1474 \\
(0.0304)\end{array}$ & & $\begin{array}{c}0.1468 \\
(0.0304)\end{array}$ \\
\hline ln Grants & & & $\begin{array}{l}-0.0504 \\
(0.0265)\end{array}$ & & $\begin{array}{l}-0.0497 \\
(0.0269)\end{array}$ \\
\hline In Likelihood & -3488.6 & -3136.4 & -1418.8 & -3135.2 & -1418.3 \\
\hline $\begin{array}{c}\text { Number of } \\
\text { observations }\end{array}$ & 8,594 & 7,483 & 2,891 & 7,483 & 2,891 \\
\hline
\end{tabular}

Note to Table 7: The columns report coefficients from logit regressions in which the dependent variable equals one if a 501(c)(3) organization has gross profits greater than $\$ 1,000$ from sales of inventory items in 1989, and equals zero otherwise. "Assets" equal the gross book value of yearend 1989 assets; "Total Expense" equals the sum of administrative and service expenses; "Total Receipts" equals the sum of contributions and grants. Regression samples exclude organizations with asset sizes below the fifth percentile of the sample, and those observations in which any independent variable (prior to taking logs) is less than $\$ 100$. All variables are measured in 1989 dollars. Standard errors are in parentheses. 


\begin{tabular}{|c|c|c|}
\hline 501(c)(3) Organizatio & $\begin{array}{l}\text { Table } 8 \\
\text { h Inventory Sales an } \\
\text { Income, } 1989\end{array}$ & Unrelated Business \\
\hline & $\begin{array}{l}\text { Unrelated business income } \\
\text { dummy }=1\end{array}$ & $\begin{array}{c}\text { Unrelated business income } \\
\text { dummy }=0\end{array}$ \\
\hline Inventory sales dummy $=1$ & 379 & 850 \\
\hline Inventory sales dummy $=0$ & 1,528 & 5,837 \\
\hline
\end{tabular}

Note to Table 8: The table presents numbers of 501(c)(3) organizations in the Form 990 sample with profits from inventory sales and with unrelated business income in 1989. The unrelated business income dummy variable equals one if an organization reports gross unrelated business income of at least $\$ 1,000$ in 1989 and equals zero otherwise. Similarly, the inventory sales dummy equals one if an organization reports gross profits of at least $\$ 1,000$ from sales of inventory items in 1989 and equals zero otherwise. The total sample of 8,594 organizations includes only those organizations in the Form 990 sample reporting total expenses and total receipts of over $\$ 100$ in 1989, and excludes organizations with asset sizes below the fifth percentile of the sample. 


\section{Table 9}

\section{Unrelated Business Income v. Profits from Inventory Sales by 501(c)(3)s, 1989}

Dependent variable equals one if an organization reports unrelated business income but no profits from inventory sales in 1989, and equals zero if an organization reports profits from inventory sales but no unrelated business income in 1989.

\begin{tabular}{|c|c|c|c|c|c|}
\hline Constant & $\begin{array}{c}-8.7158 \\
(0.5604)\end{array}$ & $\begin{array}{c}-8.1152 \\
(0.5855)\end{array}$ & $\begin{array}{l}-9.0310 \\
(0.9342)\end{array}$ & $\begin{array}{l}-13.2365 \\
(18.9341)\end{array}$ & $\begin{array}{l}-14.0390 \\
(33.8831)\end{array}$ \\
\hline ln Assets & $\begin{array}{c}0.1527 \\
(0.0649)\end{array}$ & $\begin{array}{c}0.0514 \\
(0.0697)\end{array}$ & $\begin{array}{c}-0.3504 \\
(0.1153)\end{array}$ & $\begin{array}{c}0.9825 \\
(3.5594)\end{array}$ & $\begin{array}{c}0.7440 \\
(6.1949)\end{array}$ \\
\hline$(\ln \text { Assets) })^{2}$ & & & & $\begin{array}{c}-0.0558 \\
(0.2212)\end{array}$ & $\begin{array}{l}-0.0756 \\
(0.3743)\end{array}$ \\
\hline$\left(\right.$ ln Assets) ${ }^{3}$ & & & & $\begin{array}{c}0.0011 \\
(0.0045)\end{array}$ & $\begin{array}{c}0.0017 \\
(0.0075)\end{array}$ \\
\hline ln Total Expense & $\begin{array}{c}0.6021 \\
(0.0578)\end{array}$ & & & & \\
\hline ln Service Expense & & $\begin{array}{c}0.6622 \\
(0.0660)\end{array}$ & $\begin{array}{c}0.9291 \\
(0.1083)\end{array}$ & $\begin{array}{c}0.6644 \\
(0.0665) \\
\end{array}$ & $\begin{array}{c}0.9244 \\
(0.1090) \\
\end{array}$ \\
\hline ln Admin. Expense & & $\begin{array}{c}0.0204 \\
(0.0519)\end{array}$ & $\begin{array}{c}0.1709 \\
(0.0790)\end{array}$ & $\begin{array}{c}0.0198 \\
(0.0520)\end{array}$ & $\begin{array}{c}0.1721 \\
(0.0791)\end{array}$ \\
\hline ln Total Receipts & $\begin{array}{c}-0.2152 \\
(0.0274)\end{array}$ & $\begin{array}{l}-0.2167 \\
(0.0296)\end{array}$ & & $\begin{array}{c}-0.2172 \\
(0.0298)\end{array}$ & \\
\hline ln Contributions & & & $\begin{array}{l}-0.0682 \\
(0.0521)\end{array}$ & & $\begin{array}{c}-0.0690 \\
(0.0521)\end{array}$ \\
\hline ln Grants & & & $\begin{array}{l}-0.0835 \\
(0.0476)\end{array}$ & & $\begin{array}{c}-0.0866 \\
(0.0480)\end{array}$ \\
\hline ln Likelihood & -1195.6 & -1090.3 & -520.3 & -1090.2 & -520.2 \\
\hline $\begin{array}{l}\text { Number of } \\
\text { observations }\end{array}$ & 2,378 & 2,155 & 982 & 2,155 & 982 \\
\hline
\end{tabular}

Note to Table 9: The sample is limited to 501(c)(3) organizations with either unrelated business income or gross profits of at least $\$ 1,000$ from inventory sales (but not both) in 1989. The columns report coefficients from logit regressions in which the dependent variable equals one if unrelated business income is at least $\$ 1,000$ and gross profits from inventory sales are less than $\$ 1,000$; and the dependent variable equals zero if gross profits from inventory sales are at least $\$ 1,000$ and unrelated business income is less than $\$ 1,000$. "Assets" equal the gross book value of yearend 1989 assets; "Total Expense" equals the sum of administrative and service expenses; "Total Receipts" equals the sum of contributions and grants. Regression samples exclude organizations with asset sizes below the fifth percentile of the sample, and those observations in which any independent variable (prior to taking $\operatorname{logs}$ ) is less than $\$ 100$. All variables are measured in 1989 dollars. Standard errors are in parentheses. 


\section{Table 10}

\section{Unrelated Business Income of 501(c)(3) Hospitals, 1989}

Dependent variable equals one if an organization reports unrelated business income for 1989, and equals zero otherwise.

\begin{tabular}{|c|c|c|c|c|c|}
\hline Constant & $\begin{array}{r}-13.3222 \\
(0.8760) \\
\end{array}$ & $\begin{array}{r}-12.9689 \\
(0.9395) \\
\end{array}$ & $\begin{array}{r}-13.0232 \\
(1.8527) \\
\end{array}$ & $\begin{array}{l}-67.7922 \\
(79.3376) \\
\end{array}$ & $\begin{array}{c}42.4897 \\
(106.5201) \\
\end{array}$ \\
\hline ln Assets & $\begin{array}{c}0.2107 \\
(0.1079) \\
\end{array}$ & $\begin{array}{c}0.1468 \\
(0.1172) \\
\end{array}$ & $\begin{array}{c}0.6292 \\
(0.2354) \\
\end{array}$ & $\begin{array}{c}9.4843 \\
(13.5441) \\
\end{array}$ & $\begin{array}{c}-9.6272 \\
(18.0935) \\
\end{array}$ \\
\hline$(\ln \text { Assets })^{2}$ & & & & $\begin{array}{l}-0.5290 \\
(0.7709)\end{array}$ & $\begin{array}{c}0.6246 \\
(1.0231) \\
\end{array}$ \\
\hline$(\ln \text { Assets })^{3}$ & & & & $\begin{array}{c}0.0099 \\
(0.0146) \\
\end{array}$ & $\begin{array}{l}-0.0125 \\
(0.0193) \\
\end{array}$ \\
\hline In Total Expense & $\begin{array}{c}0.5910 \\
(0.1052) \\
\end{array}$ & & & & \\
\hline In Service Expense & & $\begin{array}{c}0.5561 \\
(0.1066) \\
\end{array}$ & $\begin{array}{c}0.4314 \\
(0.2101) \\
\end{array}$ & $\begin{array}{c}0.5615 \\
(0.1073) \\
\end{array}$ & $\begin{array}{c}0.4277 \\
(0.2099) \\
\end{array}$ \\
\hline In Admin. Expense & & $\begin{array}{c}0.0958 \\
(0.0513) \\
\end{array}$ & $\begin{array}{l}-0.1486 \\
(0.1033) \\
\end{array}$ & $\begin{array}{c}0.0968 \\
(0.0515) \\
\end{array}$ & $\begin{array}{l}-0.1559 \\
(0.1038) \\
\end{array}$ \\
\hline In Total Receipts & $\begin{array}{l}-0.0903 \\
(0.0248) \\
\end{array}$ & $\begin{array}{l}-0.0900 \\
(0.0269) \\
\end{array}$ & & $\begin{array}{l}-0.0889 \\
(0.0272) \\
\end{array}$ & \\
\hline ln Contributions & & & $\begin{array}{c}-0.0994 \\
(0.0558) \\
\end{array}$ & & $\begin{array}{l}-0.0960 \\
(0.0562) \\
\end{array}$ \\
\hline ln Grants & & & $\begin{array}{c}-0.1997 \\
(0.0567) \\
\end{array}$ & & $\begin{array}{c}-0.1964 \\
(0.0572) \\
\end{array}$ \\
\hline In Likelihood & -1310.6 & -1119.0 & -308.0 & -1118.7 & -307.6 \\
\hline $\begin{array}{c}\text { Number of } \\
\text { observations }\end{array}$ & 2,173 & 1,845 & 512 & 1,845 & 512 \\
\hline
\end{tabular}

Note to Table 10: The sample is limited to nonprofit hospitals. The columns report coefficients from logit regressions in which the dependent variable equals one if a 501(c)(3) hospital has unrelated business income of at least \$1,000 in 1989, and equals zero otherwise. "Assets" equal the gross book value of yearend 1989 assets; "Total Expense" equals the sum of administrative and service expenses; "Total Receipts" equals the sum of contributions and grants. Regression samples exclude organizations with asset sizes below the fifth percentile of the sample, and those observations in which any independent variable (prior to taking logs) is less than $\$ 100$. All variables are measured in 1989 dollars. Standard errors are in parentheses. 